The author made this article openly available online. Please tell us how this access affects you. Your story matters.

McNelis, C. "Greek Grammarians and Roman Society During the Early Empire: Statius' Father and His Contemporaries" Classical Antiquity, Vol. 21, No. 1 (April 2002) pp. 67-94

Collection Permanent Link: http://hdl.handle.net/10822/551721

(C) 2002 University of California Press

This material is made available online with the permission of the author, and in accordance with publisher policies. No further reproduction or distribution of this copy is permitted by electronic transmission or any other means. 


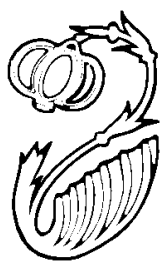

\section{Greek Grammarians and Roman Society during the Early Empire: Statius' Father and his Contemporaries}

\section{PART I: INTRODUCTION}

The first stage of education in the time of the Roman empire was grammar, a subject consisting of learning to speak properly and to explicate poetry (Quintilian Institutio oratoria 1.4.2). In a society with limited educational opportunities, grammar introduced students to the proper diction and speech patterns which were the possession of the élite. The study of grammar was thus intrinsically linked with social patterns, marking the haves from the have-nots. And because he "controlled access to the language and the education one's peers valued," the teacher of grammar-a grammarian-also exercised a degree of influence on the social fabric of the early Roman empire. ${ }^{1}$ Teachers could provide students with the resources to engage in the aristocratic discourse of their day.

I am grateful to Catherine Atherton, Thomas Frazel, Maud Gleason, Michael Haslam, Carole Newlands and Richard Rouse for their help and criticism. I owe special thanks to Leofranc HolfordStrevens for generously commenting on this piece and allowing me to read his forthcoming article on Silvae 5.3. I also thank the two readers from Classical Antiquity, whose comments improved this paper in many places.

My grandfather taught me much about education and its implications. To his memory I dedicate this paper.

1. Kaster 1988: 54. Kaster's work focuses on late antique grammarians and his conclusions may not always be applicable to the early empire. Nonetheless, the grammarian played an important cultural role for the élite even in earlier periods. As Kaster says elsewhere (1995: xxix), the lessons of the grammarian (and his more famous colleague the rhetor) "had acquired a clearly articulated and acknowledged place at the centre of the élite culture" of the late republic and early Roman empire.

Classical Antiquity. Volume 21, Number 1, pages 67-94. ISSN 0278-6656(p); 1067-8344 (e). Copyright $(C) 2002$ by The Regents of the University of California. All rights reserved. Send requests for permission to reprint to: Rights and Permissions.

University of California Press, 2000 Center Street, Ste 303, Berkeley, CA 94704-1223. 
For all their importance, however, particular teachers of grammar did not have much claim to status and did not merit much attention from ancient writers. ${ }^{2}$ Suetonius' De Grammaticis et Rhetoribus, which contains biographical stories of a number of grammarians, is a rare exception. ${ }^{3}$ Through his discussion of the lives of individual grammarians such as Verrius Flaccus and Remmius Palaemon, Suetonius outlines the development of grammatical studies at Rome during the first centuries $\mathrm{BC}$ and $\mathrm{AD}$. Moreover, Aulus Gellius wrote a fair amount about his teacher Sulpicius ( $N A 4.17 .11 ; 13.18 .2$ ) and other grammarians, if only to distinguish Sulpicius from them. ${ }^{4}$ By examining these and other stories about individual grammarians in the larger context of education in the Roman world, scholars have shed light not only on some of the people involved in ancient education but also on the processes of education itself during the early empire.

This paper considers another account of a grammarian which presents us with a store of information about Roman intellectual life. In Silvae 5.3, Statius writes about his deceased father's life and career and mentions at one point that his father was a grammarian who taught Greek poetry (5.3.146-58). Though the verses about the elder Statius' teaching have received some consideration, ${ }^{5}$ they merit deeper study, particularly in the context of education in early imperial Rome. Statius' description of his father's educational program is a significant account of Roman intellectual interaction with the Greek world (and vice versa), which illustrates that some Roman élites gained access to the prestige of education by developing their studia under the guidance of Greek grammarians. ${ }^{6}$ The importance of Greek authors and the role of Greek grammarians in Roman education was recognized by Quintilian $(1.4 .1,10.1)$. But Silvae 5.3 is a virtually contemporaneous account of the role of Greek grammarians in Roman education and one that greatly enhances our picture.

Statius' father was a teacher of Greek poetry and language-a grammatikosand he taught a range of poets, from Homer and Hesiod to Corinna, Sophron and Lycophron (5.3.146-58). The elder Statius' pedagogical activity is intriguing because the majority of the poets he taught were not among the "core" authorssuch as Homer, Euripides or Menander - who were most studied in antiquity (as evidenced by papyrological finds). ${ }^{7}$ Moreover, the poets the elder Statius is said to

2. Perhaps in part because the rhetor was more influential and respected than the grammarian. See Atherton 220-21.

3. Kaster 1995: xxiii-xxvii discusses the exceptional nature of Suetonius' work.

4. Holford-Strevens 1988: 61-63, 126; Holford-Strevens 1997: 102-103; Kaster 1988: 58ff. also discusses Gellius' relationship with Sulpicius.

5. Traglia 1128-34; Gossage 171-79; Bonner 216-17; Aricò 315-23; Fantham 175-76; Morgan 319; Holford-Strevens forthcoming. 29.

6. Literary studies of all kinds were important in the early empire. See Wallace-Hadrill 1983:

7. Morgan 71ff. discusses "core" as opposed to "peripheral" authors. Her table 15 (p. 313) lists the most commonly studied authors as attested in the papyri. 
have taught do not overlap much with the poets whom Quintilian recommends for youths training to be orators. In fact, over half of the poets mentioned by Statius are not among the ones recommended by Quintilian. ${ }^{8}$ Finally, Statius himself seems to mark out the marginal status of some of the poets taught by his father. When he completes the list of poets whom his father taught, Statius concentrates on his father's paraphrasing of Homer, not the lesser literary figures of whom he just made mention (5.3.159, quid parva loquor?).

The relatively unusual range of authors mentioned by Statius has raised some doubts about whether or not his father actually taught these Greek poets, or at least some of them. ${ }^{9}$ For the most part, however, it has been accepted that Statius' father taught these authors and that this list represents some sort of "syllabus" or "curriculum."10 Yet the incongruities between the elder Statius" curriculum and other evidence about Greek education in the Roman world have been felt. Scholars have tried to account for the elder Statius' activity by appealing to the fact that he taught in the heavily Hellenized city of Naples, a city which would welcome a diverse Greek curriculum. ${ }^{11}$ Such a view suggests that the elder Statius' syllabus reflects a local practice in an exceptionally Greek community. But surely it is significant that Statius tells us about his father's students and nowhere states that any of them were from Naples. In fact, they were aristocrats (5.3.146, generosaque pubes) from all over southern Italy and Campania, including towns such as Pompeii, Herculaneum, Surrentum, Baiae, Cumae and Misenum (5.3.162-73). ${ }^{12}$ The background of these students demands that we study the father's activity not as a Neapolitan peculiarity, but as something which had a wider significance. But how wide? Was the range of authors taught by Statius' father an aberration in the educational practices of Roman Italy? Or, did grammatikoi in other parts of the Latin West teach the poets taught by Statius' father during the early empire? Without first addressing these two interrelated questions, the historicity of the curriculum remains uncertain: at best, it presents a curious chapter of education in the Ro-

8. Also, schoolboys in Bordeaux (like Naples a Greek center in the Latin West) in the fourth century AD read authors such as Homer, Theocritus, Xenophon, and Thucydides, rather than many of the poets whom Statius mentions. See Dionisotti 100.

9. Concerns expressed by Schmid and Stählin 448n.6, 467n.9, 497n.8; LaPenna 35. Aricò counters these doubts by looking for allusions in Statius' poetry to these Greek poets in order to argue that the elder Statius taught the poets in question. Similarly, Gossage uses Statius' poetry to suggest that it was possible that the father taught these Greek poets. Such attempts discourage understanding the list in the larger context of education in the early empire by limiting the material which is brought to bear on the topic.

10. Standard accounts of ancient education or of Statius himself take 5.3 seriously. See, e.g., Morgan 319; Fantham 175-76; Holford-Strevens 1993: 211; Dewar xv; Hardie 10; Bonner 216-17; Legras 1-5. I use the words "syllabus" and "curriculum" only to designate the poets taught by the elder Statius, not in any technical sense.

11. Bonner 216. See also Wilkins 59.

12. Fantham 175 notes the Roman aristocratic background of the students. 
man world; at worst, it presents a eulogistic fiction designed to distinguish a dead parent. ${ }^{13}$

Unfortunately, there is virtually no evidence regarding the activity of grammatikoi in Naples - where the elder Statius taught - in the early empire. ${ }^{14}$ Yet, as I will show, evidence suggests that grammatikoi in Rome itself worked on the very poets taught by the elder Statius. His curriculum is therefore recognizable in the context of the intellectual activity of grammatikoi in Roman Italy and for the capital itself. Hence, while the syllabus of Statius' father includes a number of "peripheral" poets, it is nonetheless consistent with intellectual pursuits which were taking place in Rome and which were not peculiarly Neapolitan. The elder Statius' syllabus was not an isolated phenomenon.

The grammatikoi who were teaching these Greek poets at Rome likely encountered some Romans. ${ }^{15}$ It also seems reasonable that some of the elder Statius' students from towns such as Pompeii, Herculaneum, Baiae or Surrentum were Roman as well. ${ }^{16}$ How, then, did the study of these Greek poets fit into the élite discourse of Romans? What were Romans doing studying these poets? Elaine Fantham has suggested that such a course of instruction would be suitable for future poets. ${ }^{17}$ This seems likely for a few students, but it is reasonable to think that Statius' father was doing what most grammatikoi actually did-he taught poetry in order to train students for further rhetorical endeavors. After all, the main task of grammatikoi was to provide students with the preliminaries for further training in public speaking. If he was preparing students for further rhetorical training, then the elder Statius' pedagogical activity raises interesting issues, especially when one shifts attention away from the teacher and onto the students. Recent criticism has demonstrated the sociological implications of education and public speaking in the ancient world. ${ }^{18}$ Public speech was a way to demonstrate ability, a way to use language to indicate social status. In the case of the elder Statius' students, it seems obvious

13. Schmid and Stählin 448 n.6 suggest that hyperbole could be involved. Önnerfors $140-41$ comments on Statius' "Exuberanz."

14. This is not to say that grammatikoi were not at work in Naples. IG XIV.798 attests to a Neapolitan grammarian, though nothing more is known about the teacher.

15. Rome was a multicultural city in the empire, with a number of Greeks in residence. Yet, even a figure like Galen, who tried to remain aloof from Roman life while he lived in the city, dealt with Romans (Swain 357-79). Moreover, among the Roman élite, Greek learning was respected and had advantages. Wallace-Hadrill 1983: 78-86 has pointed out that the imperial courts at Rome were full of scholars with talent from both Greek and Roman backgrounds. See also Millar $83 \mathrm{ff}$.

16. I do not mean that they were Stadtrömer. But they were to a great extent "Roman." To take Pompeii as an example, people there had acquired Roman citizenship and they clearly accepted Roman practices (see, e.g., Zanker 72-132 and Laurence 20-37). Moreover, the language of inscriptions was Latin. For some ancient writers, people who spoke Latin were Romans (see Holford-Strevens 1988: 10n.9). Woolf 1998: 11 offers some interesting ways by which one could be judged Roman.

17. Fantham 175-76.

18. E.g., Gleason. 
that someone who learned Homer was certainly taking a typical course of study. But encountering Lycophron or Corinna was not typical and therefore must have provided a student who studied them with powerful resources to participate in sophisticated discourse and, potentially, to distinguish himself in such a context. Now, few Romans would have participated in this kind of activity since they lacked the resources or time to acquire the necessary skills. Even in antiquity, it was recognized that effort, time, expense, and social standing were necessary to acquire paideia. ${ }^{19}$ Sophisticated discourse therefore marks one as élite, as possessing the requirements for education. Learning the Greek poets taught by the elder Statius consequently provided access to the language of the élite and led to the possession of a desirable form of "cultural capital." 20 This knowledge not only reaffirmed social distinctions (by marking out élite from non-élite), it could also have afforded the opportunity to transform one's social status. ${ }^{21}$

An individual may utilize more than one language to generate social benefits, as recent studies of bilingualism have well argued. ${ }^{22}$ Central to understanding some of the ways individuals may gain from bilingualism is the model of codeswitching, a language practice in which individuals draw upon two or more languages in order to call into play specific forms of linguistic and cultural knowledge. ${ }^{23}$ These forms of knowledge possess certain kinds of value, some of which are related to prestige and honor. ${ }^{24}$ An individual may switch between different languages to access these values, depending upon time, place, and/or circumstance. Such a model of linguistic interaction is particularly fruitful because it allows for the coexistence of two or more languages and/or cultures. It posits an interactive relationship, in favor of a model of one-way traffic.

In studies of the interactions between the Greeks and Romans, there has been an increasing tendency to adopt a similar model of coexistence and interaction. Greg Woolf, for instance, writes:

Neither Rome's efforts to restrain Roman decadence nor Roman culture posed a major threat to Greek identity, nor were Romans ever so attracted to Hellenism that they abandoned the moral and cultural criteria on which their own sense of self was based. But the result was not a standoff . . . let alone a cultural fusion, so much as a dynamic tension that structured both cultures until the barbarian invasions. ${ }^{25}$

19. Gleason xxi.

20. Bourdieu 183-88.

21. Bloomer 13. He argues that "issues of social mobility are bound up with issues of propriety of speech."

22. E.g., Milroy and Muysken.

23. Heller 160.

24. Heller 160 .

25. Woolf 1994: 135 . 
Denis Feeney intriguingly suggests that this dynamic relationship between the Greeks and Romans is a legacy of language, of the tri-lingual semigraeci who encountered one another in the contact zones of central and southern Italy. ${ }^{26}$ So too Andrew Wallace-Hadrill has considered the energetic Greco-Roman linguistic interaction in southern Italy, specifically the Bay of Naples, in order to point out some of the ways in which people during the late republic and early empire used Latin and Greek as a way to code-switch, to indicate and create social prominence. $^{27}$

Silvae 5.3 contributes material useful for considering this dynamic interaction between Greek and Latin on the Bay of Naples. In addition, when considered in conjunction with the grammatikoi at work in Rome, the syllabus described in this poem extends consideration of Greco-Roman linguistic interaction to the capital itself. Indeed, Statius' father is a remarkable instantiation of a Greco-Roman coexistence. He was a Greek scholar and poet who taught youths from the Bay of Naples and then went on to teach Roman religion (5.3.176-84). Statius also compares his father to the Sibyl (5.3.172-75). The comparison is apt, since, like the Sibyl, whose Greek pronouncements ended up in Rome and merited the attention of Rome's rulers, Statius' father eventually moved to Rome and gained the attention of Vespasian, evidently through his poetry (5.3.195-204). The elder Statius' ability to switch between Greek and Latin-whether it be living in Hellenized Naples or in Rome, or teaching Greek poetry and Roman religion-fits nicely into the model of code-switching, "of calling into play specific forms of linguistic and cultural knowledge, forms which conventionally possess certain types of value." 28 Certainly the ability of Statius' father to employ linguistic and cultural knowledge resulted in some value, as evidenced by his acquaintance with Vespasian. ${ }^{29}$ But it is important to note that it is not just the father who gained from this linguistic and cultural knowledge. Statius informs us that his father's students gained honor as well, for they went abroad to hold administrative and military positions throughout the Roman empire (5.3.185-94). Statius' father and his students exemplify the idea that "literary and scholastic pursuits provided by far the best and most direct means of access to imperial favours." ${ }^{30}$ Silvae 5.3 provides an example of how achievement in both Latin and Greek could result in benefits both real and perceived.

Just as Gellius and Suetonius preserve precious information about the grammarian and his place in Roman cultural history, so too does Statius' poem about

26. Feeney 67.

27. Wallace-Hadrill 1998a and 1998b. See 1998a: 952-53 for important statements on linguistic interaction on the Bay of Naples.

28. Heller 160 .

29. It was probably the rare grammarian who gained access to the the emperor. See Atherton 220-22 and Kaster 1995: xlviii on the typical status of a grammarian.

30. Millar 493. 
his father. It is an account of a grammatikos and his course of instruction which sheds light on the role of Greek intellectuals in Roman society and cultural history.

\section{PART II: THE ELDER STATIUS' BACKGROUND ${ }^{31}$}

Statius' father was a master of Greek language and literature. He was from the Lucanian town of Velia (5.3.127; identified through its Greek name Hyele). Statius suggests that it was a town of strong Greek and Roman mix even in his father's day (5.3.126 ff.). Material evidence from Velia corroborates Statius' claim. For instance, Velia is only one of three cities in all of Italy which show evidence of having used Greek offices as a functional part of its constitution during the empire. ${ }^{32}$ Moreover, the political office of the $\varphi \omega \hat{\lambda} \lambda \alpha \rho \chi 0 \varsigma$, itself a Greek office, was held in the first or the early second century $\mathrm{AD}$ by people who had Greek names and were presumably of Greek origin. ${ }^{33}$ Because of its preservation of its Greek cultural heritage even after the Roman control of southern Italy, Velia was an unusual city by Italian standards.

Velia's Hellenic environment probably provided the means for the elder Statius to compete in and to win at the games in the Greek East. Statius says that his father won at the Greek literary festivals at the Nemean, Isthmian, and Pythian games (5.3.141-45). These competitions in which Statius' father competed likely consisted of poetry and oratory. ${ }^{34}$ Victories in them consequently imply a certain command of Greek literature and likely garnered some attention. His extraordinary accomplishments of winning at all of these festivals would have earned him the appellation $\pi \lambda \varepsilon\left\llcorner\sigma \tau o v i x \eta \varsigma^{35}\right.$ It is possible that an inscription in Athens attests to the father's exceptional fame and achievements in these games. ${ }^{36}$ Moreover, his Neapolitan victory will have earned him citizenship there, an honor granted by the city evidently in an effort to attract talent. ${ }^{37}$ The elder Statius would have acquired a prominent reputation (especially in Naples) as a master of Greek.

At some unknown point, Statius' father settled in Naples, where Statius himself was born (Silvae 3.5.12). Residence in Naples will have allowed the father

31. Hardie 5-14 remains the best introduction to the background of Statius' father.

32. Lomas 149. She adds (p. 153) that decrees of Velia's senate in the first century AD were bilingual (Latin and Greek) and some fragmentary decrees contain only Greek. Rawson 30-31 points out that Cicero (Fam 7.20.3) provides evidence that Velia was far from wholly Greek.

33. Lomas 176. The names were inscribed on statues which are dated from the middle of the first century to the early second century AD; see Pugliese Carratelli 243-48.

34. Hardie 6-7.

35. Hardie 7.

36. For the inscription in Athens and its possible relation to Statius' father, see Clinton 79-82. Clinton posits that the remarkable achievement of Statius' father winning the Pythian, Nemean, and Isthmian games led to the Athenian honor.

37. Hardie 8. 
to remain in a part of Italy where Greek continued to be of especial importance. ${ }^{38}$ Tacitus called it a quasi Graeca urbs ${ }^{39}$ Cicero (Rab. Post. 27), Seneca (Ep. 76.4), and Philostratus (Imagines 4) all corroborate Tacitus' statement, with Strabo ( $246 \mathrm{C}=5.4 .7$ ) offering the most explicit evidence on the Greek way of life among Romans in Naples. The literary claims are supported by material evidence. For example, inscriptions indicate the use of Greek for official decrees. ${ }^{40}$ In these inscriptions, the people of Naples are called $\delta \delta \tilde{\eta} \mu o s ;{ }^{41}$ their political officers have

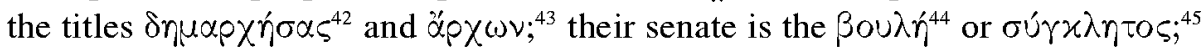

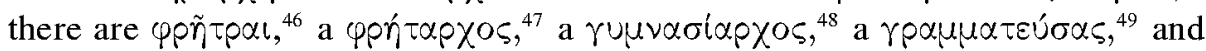
a $\delta \delta \delta \alpha \sigma x \alpha \lambda o \varsigma^{50}$ The use of Greek magistracies in official decrees certainly continued into the Flavian period and likely beyond. ${ }^{51}$ The exceptional nature of the Neapolitan use of Greek in its inscriptions is well illustrated by two inscriptions, one from Naples and one from Surrentum, commemorating Titus' assistance after an earthquake (set up sometime between January and June of 81 $\mathrm{AD}$, presumably after the earthquakes associated with the eruption of Vesuvius in 79). ${ }^{52}$ Though the inscriptions record the same or a similar act of largess by Titus to two cities only a few miles apart, the inscription from Surrentum is written only in Latin, whereas the Neapolitan decree is written in Latin and Greek. The bilingual inscription suggests that Greek was particularly important in Naples in 81 AD. ${ }^{53}$ So when the elder Statius settled in Naples, he remained in a region of Italy where Greek was particularly strong and where his outstanding accomplishments in the Greek games at Naples and throughout the Mediterranean were likely respected and honored. If an accomplished Greek poet and orator were to go anywhere in Italy, the honorary citizenship offered by Naples with its Hellenized atmosphere would certainly seem attractive.

38. Lomas passim and Leiwo are recent discussions of Naples' Hellenism.

39. Tacitus, Annals 15.33. See also Suetonius Nero 20.

40. The usage of Greek terms and offices does not mean that Naples had a Greek constitution. For a recent treatment of this vexed question, see Lomas 149-52.

41. IG XIV 737.

42. CIL X 1478, 1492; IG XIV 716, 741, 749, 756a.

43. CIL X 1489, 1490; IG XIV 741, 745, 757, 758, 760.

44. CIL X 1490; IG XIV 717, 758, 760 .

45. $I G$ XIV 719, 756a.

46. CIL X 1491; IG XIV 741, 744, 748, 759. The use of phratries is unique to Naples of Italian cities.

47. IG XIV 724, 759 .

48. CIL X 1481; IG XIV 745.

49. $I G$ XIV 741.

50. IG XIV 798.

51. Mommsen 170 says "ad id usque tempus [the Flavian period] et fortasse postea quoque acta publica Neapoli Graece confecta esse." Kaimio 71 extends the use of Greek into the third century AD.

52. The Neapolitan decree is found in Miranda 1990: 38 (number 20 in her collection). For the inscription from Surrentum, see Paci 692-704.

53. Leiwo 65. 


\section{PART III: THE "READING LIST"}

Scholars have explained the elder Statius' course of instruction as a product of this particularly strong Greek atmosphere in Naples. ${ }^{54}$ As we shall see, the same authors were taught in Rome, so there is no need to view this syllabus as peculiarly Neapolitan. The first step, however, is to consider the poets whom the elder Statius taught:

hinc tibi vota patrum credi generosaque pubes te monitore regi, mores et facta priorum discere, quis casus Troiae, quam tardus Ulixes quantus equum pugnasque virum decurrere versu Maeonides quantumque pios ditarit agrestes Ascraeus Siculusque senes, qua lege recurrat Pindaricae vox flexa lyrae volucrumque precator Ibycus et tetricis Alcman cantatus Amyclis Stesichorusque ferox saltusque ingressa viriles non formidata temeraria Chalcide Sappho, quosque alios dignata chelys. tu pandere docti carmina Battiadae latebrasque Lycophroni atri Sophronaque implicitum tenuisque arcana Corinnae.

Silvae $5.3 .146-58^{55}$

Because of this [your victories in the games], the hopes of parents

were entrusted to you, and aristocratic youths were guided by you:

to learn the behavior and deeds of the men of old, what happened at Troy, how late Odysseus was in returning, how great Homer was to describe in verse the horse and the battle of heroes,

how much Hesiod and Epicharmus enriched good rustics, in which meter the twisting voice of Pindar's lyre returns, and Ibycus, beseecher of birds, and Alcman, celebrated by the stern Amyclae, as well as fierce Stesichorus, plus Sappho, entering into men's glades,

because of her rashness not frightened by Chalchis, and others whom the lyre judged worthy. You explained the poetry of learned Callimachus, as well as the obscurities of grim Lycophron,

and Sophron's complicated work and the hidden thought of slender Corinna.

54. Bonner 216; Wilkins 59.

55. All quotations of the Silvae use Courtney's OCT. 
Of the five Greek authors most commonly studied by schoolchildren, Statius' father taught only one-Homer. ${ }^{56}$ Moreover, Quintilian includes only five of these twelve poets in his list of suggested reading (Homer, Hesiod, Pindar, Stesichorus and Callimachus). Using the terminology recently suggested by Teresa Morgan, the vast majority of the poets taught by the elder Statius are "peripheral," lying outside the "core." ${ }^{57}$ Consequently, it is necessary to expand our range of evidence in order to evaluate and to understand better the elder Statius’ pedagogical activities.

\section{PART IV: METHOD AND EVIDENCE}

Three types of evidence are available to determine whether other grammatikoi were concerned with the poets mentioned in the elder Statius' curriculum: evidence from scholia, from papyri, and from the Suda. ${ }^{58}$ Scholia and Suda entries often provide information about the activity of grammatikoi in Rome, so they are especially useful for creating an intellectual context for teachers of Greek in the early empire. In addition to information directly pertinent to Rome, Egyptian papyri are useful for evaluating the activity of grammatikoi in Roman Italy in a number of ways. First of all, papyri attest to the existence of grammatical commentaries on specific poets and thus provide clear evidence about which poets were the subject of criticism by grammatikoi. Commentaries are not proof of teaching, but it is a reasonable assumption that if a critic wrote on a certain poet, he-or another-also likely taught about the poet. Moreover, Egyptian criticism on Greek poets is relevant to the activity of grammatikoi in Rome because some papyri from Oxyrhynchus contain the work of grammarians who we know were at work in Rome. ${ }^{59}$ Papyri therefore attest to the circulation of grammatical work from Rome to regional centers of Egypt. And, as will be seen, the work of a few grammatikoi who worked at Rome on some of the very authors taught by the elder Statius has been found in Oxyrhynchus. Evidence preserved in the Egyptian sands thus helps to fill in the intellectual context of grammatikoi throughout the early empire by providing material witness to their activity in Egypt and in Rome.

Oxyrhynchus also provides a larger look into Greek intellectual activity in Rome. The relationship between Oxyrhynchus and Rome necessarily involves Alexandria, which was "the town to which inhabitants of Oxyrhynchus resorted for their higher education, and through which they learned of countries outside

56. Morgan 313 provides a table of the most common authors judging from the papyri. The first five are Homer, Euripides, Menander, Isocrates (gnomic), and Diogenes (gnomic).

57. See Morgan 71ff. on "core" and "peripheral."

58. Fraser 448.

59. Turner 1-2 discusses the example of L. Annaeus Cornutus, who taught Persius and whose works were found in Oxyrhynchus. 
Egypt." ${ }^{60}$ Imperial Rome had a special relationship with Alexandria ${ }^{61}$ Chaeremon, for example, was a head of the Museum at Alexandria and also seems to have been Nero's teacher. ${ }^{62}$ Further, it seems that Dionysius of Alexandria was in charge of the libraries at Rome roughly from the time of Nero to the time of Trajan. ${ }^{63}$ In the Flavian period, Domitian sent scribes to Alexandria to replenish texts lost, presumably, in the fires which destroyed the library connected to the Porticus of Octavia. ${ }^{64}$ These are a few specific examples which are part of the general movement of Alexandrian scholarship to Rome during the early empire. ${ }^{65}$

Egypt, then, provides insights on Roman intellectual life in a number of ways. Consequently, in the few instances where grammatical activity is attested in Egypt but not in Rome for the authors taught by the elder Statius, it is worth considering the fuller intellectual context of Greek education outside of Rome during the early empire. So, making use of extant scholia, the Suda, and papyri from Oxyrhynchus, let us turn to examine the authors taught by the elder Statius in conjunction with the evidence of other grammatical activity at Rome and Egypt in the early empire. ${ }^{66}$

\section{PART V: GRAMMATIKOI AND THEIR WORK}

Statius' account of his father's teaching begins with epic and didactic poetry. Homer is naturally the first poet whom Statius mentions (5.3.149-50). Roman writers state that the Iliad and Odyssey were the first Greek writings read at school, so there is no reason to doubt that a grammatikos taught Homer. ${ }^{67}$ An anecdote in Aulus Gellius (NA 1.6.1) reveals that a familiarity with the Iliad could be widespread. He suggests that when Cicero (and Tiro) made a mistake in the De Gloria about the attribution of certain lines from Iliad 7, even those who were not scholars might have been able to pick out the error. Gellius thus implies that even the speakers of verses in Iliad 7 would have been familiar. Aristonicus, who lived in Rome before and during Tiberius' reign and who wrote on both the Iliad and Odyssey, and Seleucus, who is said to have commented on virtually

60. Turner 9.

61. Pfeiffer 1968: 274 writes that scholarship "gained new life in Rome, and even in Egypt the growing interest of Caesar, Mark Antony and Augustus ... had an encouraging effect on scholars."

62. Turner 3-4; Millar 87.

63. Millar 87.

64. Suetonius Domitian 20; for the fire, see Cassius Dio 66.24.2. Our state of knowledge of the rebuilding and destruction of Roman libraries is poor and we cannot be certain which library was burned in the fire. See Fehrle 66. The library connected to the Temple of Augustus was also destroyed by fire and could just as well be the library that had to be replenished.

65. Fraser 474 writes, "After Theon, Alexandrian scholarship moves to Rome ... and enters a new environment in which it soon loses its particular association with Alexandria."

66. Some of the following information about grammarians may be found in works such as Hillscher and Mazzarino. I have not found any work which catalogs in detail Flavian or post-Flavian grammarians, so my survey is intended to be representative, not exhaustive.

67. Quintilian 1.8.5; Pliny Ep. 2.14.2. 
all poetry, are two examples of the presumably many grammatikoi who taught Homer in early imperial Rome. ${ }^{68}$

Hesiod (5.3.150-55) also merited commentaries. Aristonicus wrote a treatise

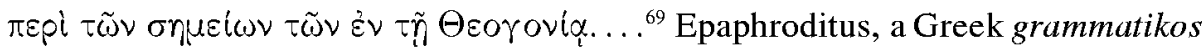
living at Rome from the time of Nero to Nerva, wrote on the Scutum. ${ }^{70}$ Plutarch, by no means merely a grammatikos, was a frequent visitor to Rome (even under Domitian, who banned philosophers from Rome in 93 or 94) and gave lectures there.$^{71} \mathrm{He}$ also wrote a four-book commentary on the Works and Days, the poem to which Statius refers through the phrase pios ditarit agrestes. ${ }^{72}$ As with Homer, it is not unusual that a Greek grammatikos taught Hesiod in Italy in the first century AD.

Statius next mentions Epicharmus (5.3.151) as one of the poets his father taught. ${ }^{73}$ In particular, Statius refers to Epicharmus' agricultural usefulness. Columella also says that Epicharmus should be read ( $D R R$ 1.1.15) for his agricultural value, thereby providing some evidence that his work was available to be read in early imperial Rome. In addition to agricultural advice, Epicharmus was also studied for his words of wisdom or $\gamma \nu \tilde{\omega} \mu \alpha$ ( Theocritus Epigram 18). Wise sayings formed the basis of education in both the Greek and Roman worlds. ${ }^{74}$ It is thus possible that Epicharmus was studied in Roman Italy as a source of maxims. ${ }^{75}$ At any rate, there was a long tradition of grammatical exegesis on Epicharmus' work. For example, Apollodorus of Athens (second century $\mathrm{BC}$ ) wrote a commentary on Epicharmus which was at least six books long. ${ }^{76}$ It is possible that behind Gellius' quotation (NA 1.15) of Epicharmus lurks the teaching of the Greek grammarian

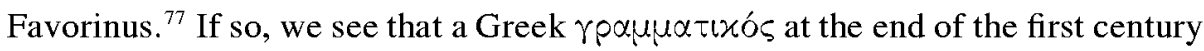
AD or the early second century AD provided access to Epicharmus. In Rome of the Flavian period, Epaphroditus provides certain evidence for grammatical exegesis

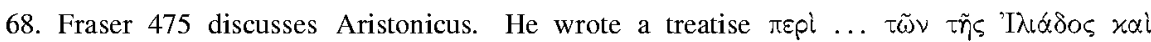

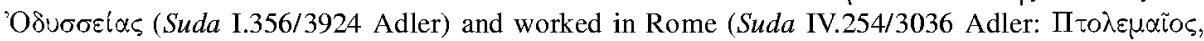

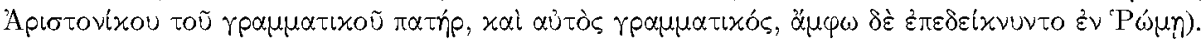
Seleucus is likewise reported to have worked in Rome (Suda IV.337/200 Adler: A $\lambda \varepsilon \xi \alpha \nu \delta \rho \varepsilon u s ~ \gamma p \alpha \mu-$

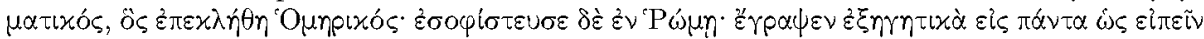

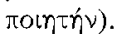

69. Previous note (Suda I.356/3924 Adler).

70. For Epaphroditus, see Luenzner; Christes 103-104; Lehnus 369-73; Cairns 218-22.

71. Jones 22-27 outlines Plutarch's connection with Rome during the Flavian period.

72. West 1978: 67 for Plutarch's commentary.

73. Statius does not mention Epicharmus by name, only through the phrase Siculusque senex. There is a consensus that Epicharmus is meant.

74. Cribiore 44-45.

75. Epicharmus' poetry was included in Hellenistic collections of verse maxims; see $R E$ Supplement 6, 78 (34-40) s.v. Gnome. Indeed P. Petrie III.I.I. preserves some $\gamma v \tilde{\omega} \mu \alpha \iota$ which contain Epicharmus; P. Hibeh I.1 attests to the presence of the Pseudepicharmea in such works. Cronert has arranged the extant Epicharmean $\gamma v \tilde{\omega} \mu \alpha$.

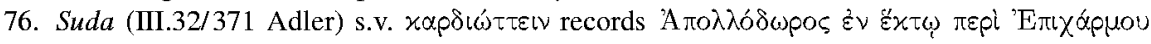

77. Holford-Strevens 1988: 174. For Favorinus, the man from Arles who learned Greek and used it professionally, see Holford-Strevens 1988: 72-92. 
on Epicharmus. ${ }^{78}$ So Statius' claim that his father taught Epicharmus coheres nicely with the intellectual activity of other grammatikoi in Rome and throughout the Roman world during the early empire.

The next component of the father's course of instruction involves lyric poetry. Pindar (5.3.151-52) is the first lyric author named by Statius. Didymus wrote a great commentary on Pindar during the late republic or early Augustan age. His student Apion was in Rome up to the middle of the first century AD and there is evidence that he too worked on lyric. ${ }^{79}$ Heracleides Ponticus (the younger) was another student of Didymus in Rome at this period. ${ }^{80}$ Perhaps such individuals perpetuated grammatical exegesis on Pindar at Rome. ${ }^{81}$ In any case, Tryphon, an Alexandrian grammatikos who was at Rome during the Augustan age, wrote a treatise on dialects which included Pindar. ${ }^{82}$ A little later, the same Aristonicus who wrote a treatise on the Theogony of Hesiod worked on Pindar. ${ }^{83}$

In the case of Ibycus (5.3.152-53), there is no evidence that his poetry was the subject of grammatical work in Italy. P.Oxy 2637 is a second-century commentary on choral lyric which quotes Ibycus. ${ }^{84}$ Otherwise, there is little explicit testimony. Likewise, there is not much evidence that grammatikoi worked on Stesichorus

78. Luenzner F 6. Daniel 30-36 argues that Epicharmus is one of the figures represented in a late antique mosaic. Perhaps his was just a name by that point, but it is interesting that Epicharmus may have been important even into late antiquity.

79. Suda (I.288/3215 Adler) records the following for Apion: A Aí $\omega \nu, \delta \Pi \lambda \varepsilon\llcorner\sigma \tau o v i x o v, \delta$

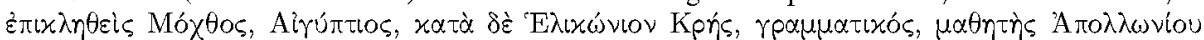

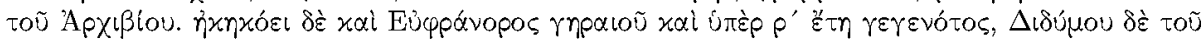

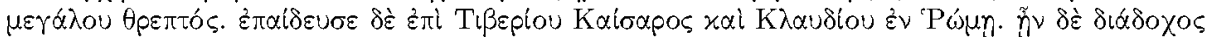

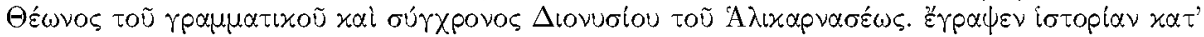
$\varepsilon \theta \vee \circ \varsigma x \alpha l \alpha \lambda \lambda \lambda \alpha \tau \downarrow \alpha \alpha$. Apion was seen in Rome by Pliny (see Cameron $191 \mathrm{n} .33$ ). Leofranc HolfordStrevens kindly advises me that the $S u d a$ appears to be in error regarding Apion's father: it was Apion himself, not his father, who was $\Pi \lambda \varepsilon\llcorner\sigma \tau o v i x n s$.

80. Suda (II.582/463 Adler) provides the following for Heracleides Ponticus: 'Hpax $\lambda \varepsilon i \delta n s$,

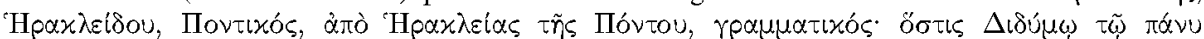

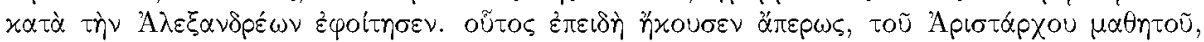

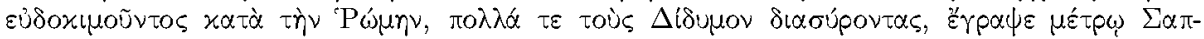

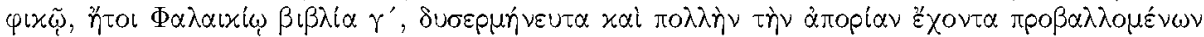

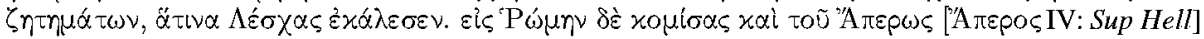

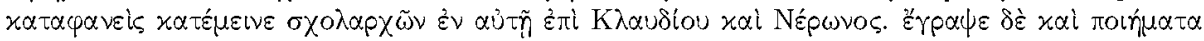
$\varepsilon \dot{\pi} \pi \dot{\alpha} \pi \sigma \lambda \lambda \dot{\alpha}$.

81. Didymus' works were used in Flavian Rome by Epaphroditus. See Luenzner 11-12. It is also interesting to note that Didymus' commentary on Pindar ended up being quoted by Lactantius (Divine Institutes 1.22 .19 ). Ogilvie 48 notes that this citation was likely preserved by a commentary on the Aratea which incorporated quotations from Musaeus, Ovid, Cicero, and Germanicus. The relevant point here is that Didymus' work on Pindar was available in a place where grammarians in the Latin world could cite Didymus along with Musaeus and the Roman poets.

82. Suda (IV.601/1115) records the following title for one of Tryphon's works: $\pi \varepsilon \rho i ~ \tau \tilde{\omega} \nu \pi \alpha \rho^{\prime}$

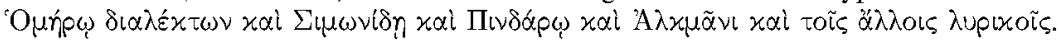

83. $\Sigma$ Pindar Olympian I.35c, III.31a and VII.154a (Drachmann). Although there are no extant fragments of the work, Epaphroditus was said to have written about Pindar (see Luenzner 18). If Epaphroditus did, then there would be more evidence of a grammatikos at Rome working on Pindar.

84. Lobel 1967. 
(5.3.154). However, P.Oxy 2506, a papyrus of the first or second century AD, includes work on Stesichorus (as well as other lyric authors). ${ }^{85}$ It is also worth keeping in mind that Quintilian includes Stesichorus in his list of recommended reading, thereby suggesting availability. Of all the authors from the elder Statius' course of instruction, Stesichorus and Ibycus afford the least evidence that their poetry was the subject of grammatical criticism in Rome.

Papyrological finds attest that numerous commentaries were written on Alcman (5.3.153). The Louvre papyrus (written in the first century AD) of Alcman's Partheneion includes three columns of text as well as scholia. Five scholars (Aristophanes, Aristarchus, Pamphilius, Sosiphanes, and Stasicles) are mentioned in the scholia in conjunction with variant readings or interpretations of the text. Sir Denys Page pointed out that the mention of these other scholars suggests that the Louvre scholia are a compilation of other commentaries on Alcman. ${ }^{86}$ In addition to the Louvre papyrus, five commentaries which seem to concern Alcman have survived: Edgar Lobel identified P.Oxy 2388 and 2389 as commentaries on Alcman written in the second half of the first century AD; P.Oxy 2390 (second century AD), 2392 (second century AD) are commentaries on Alcman, and 2391 (first century AD) probably is. Finally, P.Oxy 2393 is a second-century AD lexicon on Alcman. ${ }^{87}$

All this grammatical work on Alcman attests to a strong tradition in Egypt, which can be paralleled to some extent in Rome. The same Tryphon who worked on Pindar included Alcman in his treatise on Spartan dialects. The label from this work was preserved at Oxyrhynchus, providing a material witness to the movement of grammatikoi and/or their works between Rome and Egypt ${ }^{88}$ Also, a marginal note in P.Oxy 2387 fr.1 reveals that Aristonicus questioned the location of an ode or strophe in a fifth book. ${ }^{89}$ The poetry in question is Alcman's. If this Aristonicus is the same grammarian who was working in Rome, then again a connection can be made between Rome and Egypt regarding the study of Alcman. ${ }^{90}$ There does not seem to be any later evidence for grammatikoi in Italy continuing to teach Alcman, but the papyri from Oxyrhynchus suggest that the commentary tradition on Alcman's poetry was continuous. So, Statius' claim

85. Page 1963b.

86. Page 1951: 10.

87. Lobel 1957: 28-86.

88. The preserved label is now P.Oxy 2396. See also Turner 4 n.8.

89. Edited by Lobel 1957: 11:

$$
\begin{aligned}
& ] \tau \alpha[
\end{aligned}
$$

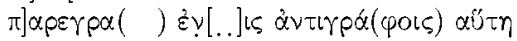

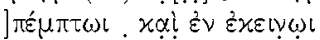

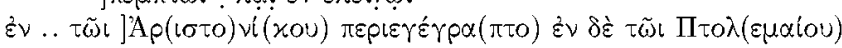

$$
\begin{aligned}
& \dot{\alpha} \pi \varepsilon p[i] \gamma p \alpha(\pi \tau o s) \tilde{\eta} v
\end{aligned}
$$

90. The identification of Aristonicus as the author of this note is open to objection, as the name in the papyri is given only as Apví. Pfeiffer 1968: 221 assumes the Aristonicus to be one and the same. Lobel 1957: 11 seems to assume it as well. 
that his father taught Alcman seems reasonably consistent with the activity of other grammatikoi in Rome and in Egypt.

Statius next says that his father taught Sappho (5.3.154-56). Didymus' $\Sigma u \mu \pi \sigma \sigma \alpha \alpha \alpha \dot{\alpha}$ contains "some trifles of genuine learning on ... Sappho."91 A later commentary (early second century $\mathrm{AD}$ ) on Greek lyric poets is preserved in P.Oxy 2506. Sappho's poetry was discussed in this work. ${ }^{92}$ Also at this time, Apollonius Dyscolus commented upon Sappho, as did Hephaesteion. ${ }^{93}$ In the middle of the first century $\mathrm{AD}$, Heracleides Ponticus, a grammatikos living at Rome, wrote poems in Sapphic meters. ${ }^{94}$ Sappho's meters were of course also known to Catullus, Horace, and Seneca, attesting to a strong literary interest in Sappho's poetry during the late republic and into the early empire.

Callimachus was also part of the father's curriculum (5.3.156-57). This is to be expected since Callimachus' poetry received attention from grammatikoi almost immediately. Rudolph Pfeiffer pointed out that grammatikoi from the time of Aristophanes of Byzantium onwards quote Callimachus more than any other Greek poet but Homer. ${ }^{95}$ A papyrus fragment of the Victoria Berenices, written within a generation of Callimachus' death, is interspersed with notes and shows that grammatical interest in Callimachus was almost immediate. ${ }^{96}$ Later grammarians maintained this interest. Theon wrote a famous commentary on Callimachus during the Augustan age and later scholars in Egypt continued to work on Callimachus. For example, a grammatikos whose work was found at Tebtunis wrote "short prose accounts of the contents of Callimachus' poems" in the early second century. ${ }^{97}$ The interest in Callimachus' poetry is also attested at Rome: Epaphroditus wrote on Callimachus' Aetia, providing evidence for grammatical interest in Callimachus' poetry during Statius' lifetime. ${ }^{98}$ And of course, the enormous impact of Callimachus on Roman poetry well into the early empire also bears witness to his presence at Rome. With Callimachus, the elder Statius' syllabus fits into a recognizable context for the activity of a grammatikos in the Latin West during the early empire.

There is little explicit evidence for grammatical work on Lycophron, whom Statius says that his father taught (5.3.157). Alan Cameron suggests that the

91. Pfeiffer 1968: 279.

92. Page 1963b: 38.

93. Cf. Lobel and Page passim.

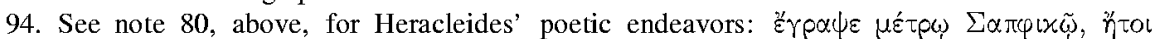
$\Phi \alpha \lambda \alpha \alpha x_{i} \omega \beta<\beta \lambda i \alpha \gamma^{\prime}$. The Greek here may mean that Sapphic and phalaecian verses were used interchangeably, thus suggesting that we are not dealing here with the Sapphic stanza. Indeed, no Sapphic stanzas exist in Greek after the Hellenistic period except for those of Melinno (West 1982: 149), but the presence of Sapphic stanzas in the Latin poets suggests that the form was still known and used at Rome at the time Heracleides was at work there.

95. Pfeiffer 1953: xxvi, xxx.

96. Parsons 4.

97. Van Rossum-Steenbeek 76.

98. Luenzner F 53-58. 
Alexandra "must have been equipped very early with explanatory glosses," but the earliest commentary we know of is Theon's. ${ }^{99}$ Wilamowitz made the point that ancient commentators on Vergil often took matters over from Lycophron's, thereby suggesting that grammatikoi were reading Lycophron and his commentators in Rome. ${ }^{100}$ Indirectly, then, there is evidence that Roman grammatikoi were reading and working with Lycophron's poetry and commentaries on it.

Sophron also appears in the curriculum (5.3.158). Sophron wrote mime, a type of literature which was particularly associated with Campania. ${ }^{101}$ Perhaps, then, Sophron's work was particularly attractive to Campanian students. But Sophron was also studied by grammatikoi throughout the Mediterranean. In the second century BC, Apollodorus of Athens wrote a Пepi $\Sigma \hat{\omega} \varphi p o v o s$, a work of at least four books. Apollonius Dyscolus (second century AD) also worked on Sophron. ${ }^{102}$ Sophron's work was also known at Rome: Varro cites Sophron's Greek to explain the etymology of mutuum ( $L$ 5.179), and Herodian included Sophron in some of his exegesis. ${ }^{103}$ Finally, Demetrius of Laconia wrote about Sophron to some degree in his treatise on poetry: he discusses the meaning of

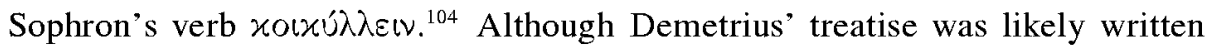
sometime during the early first century BC, it is relevant to the elder Statius' lifetime because it was found among the Herculanean papyri buried in 79 AD. Consequently, a grammatical work which dealt_-if only in part-with Sophron's writings was available on the Bay of Naples during the elder Statius' lifetime.

The final poet mentioned is Corinna (5.3.158). Page claims that "it seems likely that she was studied by grammatici in the first century BC."105 Indeed, grammatikoi such as Alexander Polyhistor (who worked at Rome in the first century $\mathrm{BC}$ ), Apollonius Dyscolus, and Hephaestion worked on Corinna's poetry. ${ }^{106}$ P.Oxy 2370 , dated to ca. $200 \mathrm{AD}$, is a witness to such exegesis, as it "must be presumed ... to represent activities of a commentator." ${ }^{107}$ Moreover, Apollonius Dyscolus quotes a passage of Corinna and prefaces it by naming Tryphon and Habron as authorities on the Boeotian dialect. ${ }^{108}$ Page concludes, "it appears reasonable to suppose that these two scholars were familiar with her work." 109

99. Cameron 224.

100. Wilamowitz-Moellendor ff 144 ("wenn bei den Römern sonst keine Spur von ihr gefunden ist, so beweist die Herübernahme von Scholien zu ihr in die Vergilerklärung, daß die Grammatiker sie lasen"). As one of the readers points out, there could have been interest in Lycophron at Rome because of the Alexandra's predictions of Roman rule. S. West 132-35 makes a strong case for Vergil's own knowledge of Lycophron.

101. Hardie 60 discusses mime in Campania.

102. Gow 34.

103. See Kaibel F 134 and F 135.

104. Romeo 286.

105. Page 1963a: 71.

106. Rawson 55 discusses Polyhistor on Corinna.

107. Lobel 1956: 61.

108. Page 1963a: 30.

109. Page 1963a: 70. 
It would be interesting if Habron actually did work on Corinna, since he lived and worked at Rome during Tiberius' reign. ${ }^{110}$ Tryphon, too, worked in Rome. The likely familiarity of these critics with her poetry suggests that grammatikoi at Rome were working on Corinna. ${ }^{111}$

To sum up: there is no evidence as yet that Ibycus was commented upon or taught in Rome. There is testimony that grammarians were interested in Sappho's poetry, and literary interest also suggests her poetry was read. Sophron's work merited attention. Proof that Stesichorus was studied is scanty, though his work is recommended by Quintilian. And for the bulk of the list, there is strong evidence that these poets attracted the interest of grammarians in Rome during the early empire. Pindar and Alcman were certainly studied in Rome in imperial times, and it is highly likely that Corinna was. Indirect evidence indicates that Lycophron was studied as well. There is direct evidence that Callimachus, Epicharmus, Hesiod, and of course Homer were the subject of grammatical criticism in Rome during the Flavian period. Thus, extant evidence suggests that almost half of the elder Statius' curriculum is consistent with the activity of other Greek grammatikoi in Rome of his lifetime; other authors were studied in Rome only a generation or two before his time. A few generations of silence need not be troublesome, for as Morgan argues, the nature of ancient education was relatively stable. ${ }^{112}$ Hence the elder Statius' curriculum is consistent with the known activity of grammatikoi in Rome and Roman Italy during the early empire.

\section{PART VI: MORE ON GRAMMATIKOI AND THEIR WORK}

The Suda entries mention that grammatikoi worked on almost half of the poets taught by the elder Statius because of their dialects. ${ }^{113}$ In fact, familiarity with the standard dialects of Greek and Latin as well as with poetry composed in different dialects was expected. ${ }^{114}$ Perhaps Statius' father too taught some of these poets

110. Suda (I.13/97 Adler) provides the following on Habron: $\Phi$ pì

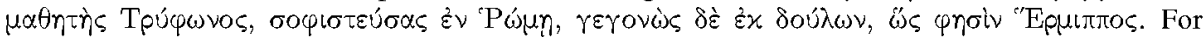
Habron's date, Christes 93 says, "kann Habron bis in die Zeit des Tiberius hinein in Rom gewirkt haben." See also Turner 4.

111. For further discussion of Corinna in Rome and in particular Statius' description of her work, see Burzacchini.

112. Morgan 3.

113. Wouters 213-14 notes that Greek grammarians had extensive interest in literary dialects, perhaps in an attempt to justify any lack of regularity. Quintilian also mentions the problems posed by dialectal variation (1.5.29), though for him the variations are part of a larger catalog of vices which a student faces in learning to speak well. Nonetheless, when all these flaws are eliminated, Quintilian says the result will be correct and clear speech with a pleasant sound (1.5.33, Remotis igitur omnibus

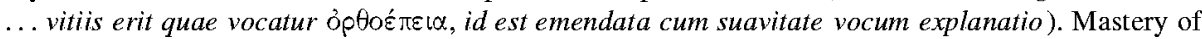
dialectal variation is thus one step in the process of achieving proper speech-ỏp $\theta 0 \varepsilon ́ \pi \varepsilon เ \alpha$. Moreover, mixing dialects was a problem to which Quintilian and other experts in public speaking were sensitive (8.3.59).

114. Atherton 224, 229, 243. 
because they were appropriate for the study of different dialects. Homer, Hesiod, and Sappho would be likely candidates for such studies. In addition, Corinna was evidently included in grammatical exegesis on Boeotian dialect. Pindar would also offer some instances of Boeotian usage. But Pindar, like the core of the list, would be a poet illustrative of Doric dialects. Epicharmus, for example, wrote in Sicilian Doric-hence Statius' use of the epithet Siculus. Indeed, our one fragment from

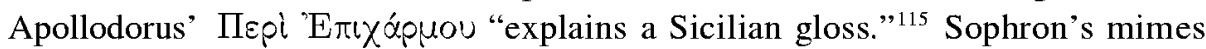
were also in Doric. ${ }^{116}$ Apollodorus' work on Sophron included grammatical "explanation of the rare Syracusan dialectal words and forms."117 Apollonius Dyscolus discussed Sophron's Doric adverb $\pi \varepsilon \tilde{\imath}$ three times, suggesting some of the interests he had. ${ }^{118} \mathrm{He}$ also used Alcman, another of the elder Statius' authors, "as a principal source for Doric." 119 As will be seen, Stesichorus and Ibycus were also useful for studying Doric dialects.

The study of the Doric dialects of the authors taught by Statius' father would likely have had special relevance in Magna Graecia. Epicharmus, Sophron, Ibycus, and Stesichorus were from Sicily and employed Doric dialects. ${ }^{120}$ As the work of Apollodorus and others attests, these poets were studied in part because their language and usage was representative of the Doric dialects. ${ }^{121}$ Even though the use of Greek dialects declined throughout the Hellenistic and Roman periods, ${ }^{122}$ they were not completely eliminated. For example, the extant public archives of Tauromenium (IG XIV.422-30) are written in Greek, mostly in a Doric dialect. ${ }^{123}$ The dates of the archives range from 120 to $36 \mathrm{BC}$, a period just before the time of Statius' father. ${ }^{124}$ A few later writers suggest that some people throughout the Greek world were still familiar with Doric. ${ }^{125}$ Moreover, it is noteworthy that during the imperial period in Naples, a Greek

115. Pfeiffer 1968: 264.

116. Latin writers were also aware of Sophron's Sicilian dialect. Varro ( $L L 5.179)$ cites him as an example of it.

117. Pfeiffer 1968: 265.

118. Gow 34.

119. Page 1951: 102n.1.

120. For a linguistic treatment of Doric in Sicily, see Lardi $3-42$.

121. Indeed, Dubois 204, 226, 230 notes similarities between the language of inscriptions from Sicily and the language of Epicharmus and Sophron.

122. On the well-known decline of dialects in the Greek world, see Bubeník and Zgusta 123-24.

123. Guarducci 290; Kaimio 69.

124. There was a dramatic change to the use of Latin in the Sicilian epigraphy under Augustus (Mommsen 714 notes the decisive period), so one needs to be cautious about using Republican evidence to evaluate later usage. However, Latin supplanting Greek in the inscriptions need not mean that the use of Greek was eradicated. Indeed, ca. $200 \mathrm{AD}$, Tauromenitans set up an inscription in Rome which was written in Greek ( $/ G$ XIV.1091). See further Wilson 315-16.

125. Debrunner 35-36 collects ancient evidence (Strabo, Pausanias, Dio of Prusa). Zgusta 124 notes that these writers present situations which were likely not typical. In addition to the passages cited by Debrunner, Swain 60 notes that Galen (Thrasybulus v.868.1-869.7) stresses the importance of having a knowledge of Ionic, Doric, and Aeolic in addition to a thorough knowledge of Atttic. The survival of the dialects (and Greek, for that matter) in the West is a complex topic. See Wilson 
poem which was written for an epitaph started with two Doric words ( $C I L$ X.1494 Tpeivaxpi $\alpha \alpha i \alpha \mu \varepsilon \lambda o \chi \varepsilon \dot{u} \sigma \alpha \tau o)$ to evoke the dead woman's Sicilian origin. ${ }^{126}$ Seven more lines of the epitaph are written in Greek. However, it is intriguing that the epitaph ends with two Latin verses: Cornelius scriba coniugi / incomparabili contra votum. So what we have is a somewhat educated (scriba) Latin speaker living in Naples who composed a poem (or had it written) which used Doric forms in honor of his Sicilian wife. The inscription remarkably creates a sense of fluid interaction between Latin, Greek, Doric, Naples, and Sicily. Knowledge of the Doric representative of Sicily was still useful into the Roman period, whether for a town's public archives or to honor a dead wife. It seems reasonable, then, that a grammatikos teaching poets such as Epicharmus in Magna Graecia would continue the tradition of dialectical exegesis on these western Greek poets.

However, the study of the language of these western Greek writers was not limited to southern Italy. We know that work on Doric dialects took place at Rome. Philoxenus wrote on Syracusan and Laconian dialects during the late republic, ${ }^{127}$ and Pacatus wrote on Doric dialects some time during the first century AD. ${ }^{128}$ In the second century AD, Herodian commented on specifically Doric aspects of the language of Sophron and Epicharmus. ${ }^{129}$ Also, Tryphon, the grammatikos of the Augustan age, included Alcman in his study of Spartan dialect. His work deserves special consideration. The Suda informs us that Tryphon wrote one treatise on the dialects of Homer, Pindar, Alcman, and other lyricists and a second on dialects of regions such as Himera, Rhegium, and Syracuse. ${ }^{130}$ Lobel wrote that

313-19 for an illuminating discussion of the varied survival of Greek in places such as Syracuse, Palermo or Termini Imerese.

126. See Miranda 1995: 73 and Peek 292 for the inscription and date. Leiwo 56-57 also discusses the inscription and the Doric form $\gamma \alpha i \alpha$ (which has a long final alpha).

127. Suda (IV.729/394 Adler) provides the following about Philoxenus: A $\lambda \varepsilon \xi \alpha \vee \delta \rho \varepsilon u ́ \varsigma, ~ \gamma p \alpha \mu-$

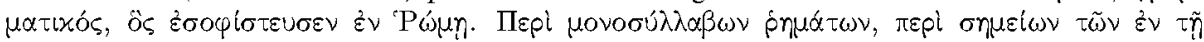

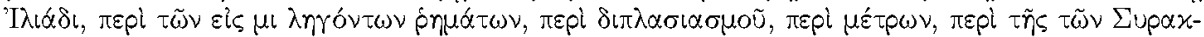

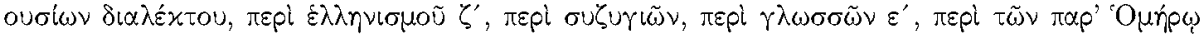

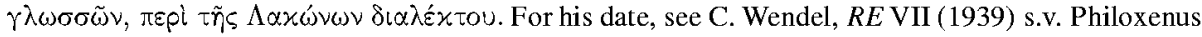
$194,26-42$.

128. Pacatus is the Latin name of the Greek grammarian Eirenaios. Suda (IV.4/29 Adler)

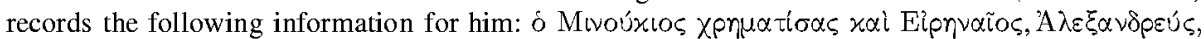

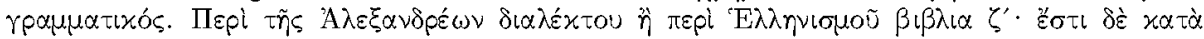

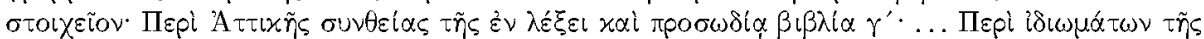

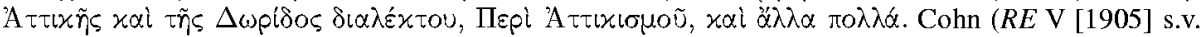
Eirenaios 2121, 4-11) argues that the Latin name plus his orthographical interest in K $\alpha \pi \varepsilon \tau \omega \lambda$ เov speaks for his connection with Rome. He may in fact be the same Pacatus mentioned by Seneca (Controversiae X.10.11).

129. For Herodian on Doric and Epicharmus, see Kaibel F 115; for Herodian on Sophron's usage of Doric, F 134 and 135.

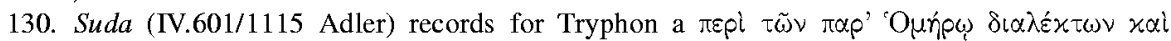

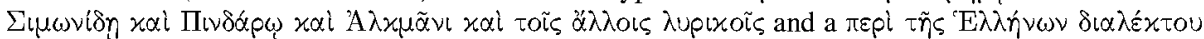

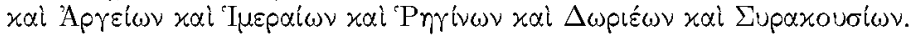


the absurdity of these titles shows that they cannot be taken at their face value. A book about the dialect used by an author, say Alcman,

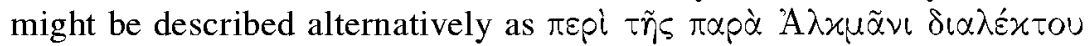

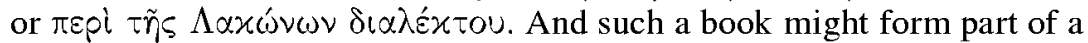

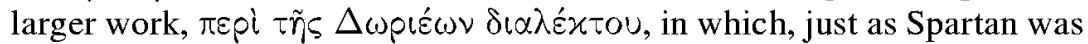
illustrated from Alcman, the speeches of Syracuse, Himera and Rhegium were illustrated from Epicharmus (and the other comedians), Stesichorus and Ibycus.... ${ }^{131}$

Lobel's statement about how a book on dialects would have been put together raises interesting possibilities. To my knowledge, it is a view which is not based upon any hard evidence, but rather the fact the Suda mentions Himera and Rhegium as two cities whose dialects were discussed. Stesichorus and Ibycus were famous authors from these two cities. If Lobel should be correct in suggesting that the Suda's report of the title of Tryphon's work on dialects from Syracuse, Rhegium, and Himera "hides" a book which would have included Epicharmus, Stesichorus, and Ibycus, it would have interesting consequences for the list of poets the elder Statius taught. For Ibycus and Stesichorus would have been discussed by Tryphon (who of course spent some time at Rome). Though a bit earlier than the elder Statius' lifetime, Tryphon's work nonetheless may offer some witness to additional grammatical exegesis on Ibycus and Stesichorus in Rome.

Our evidence suggests that the elder Statius' course of instruction sits reasonably well in the intellectual context of Greek grammatikoi at Rome and beyond. Nonetheless, his choice of authors goes beyond the most common authors studied in antiquity. The next question, then, is why grammatikoi such as Statius' father were teaching these less conventional poets.

\section{PART VII: WHY?}

The job of a grammatikos was to start the process whereby students gained the linguistic mastery necessary for oratorical success. And there is no reason to suspect that Statius' father was up to something different, for he taught poetry appropriate for rhetorical training. ${ }^{132}$ The grammarian's task was to teach poetry, the goal of which was to ensure that students read correctly (Quintilian 1.4.3). Now, proficient language was a badge of élite identity. ${ }^{133}$ Consequently, the grammarian would start the process of weeding out of children's speech all the poor language they had picked up in the usual discourse of their lives. ${ }^{134}$ Another consequence of studying with a grammarian would be a knowledge-in

131. Lobel 1957: 90.

132. Oribasius suggested that educated people should declaim poetry from memory for vocal exercise. Epic hexameters are optimal, but other genres such as drama or lyric are acceptable. Gleason 88 brought this passage to my attention.

133. Swain 64 .

134. Atherton 233. See also Connolly 134-35. 
at least a few cases surely an extensive knowledge-of the poetry which had been scrutinized syllable by syllable, line by line. In fact, Quintilian emphasizes the importance of comprehension of poetry for proper speech $(1.8 .2$, unum est igitur quod in hac parte praecipiam, ut omnia ista facere possit: intellegat). The resulting knowledge of the poets taught by the elder Statius would vary according to background. For an élite western Greek such as Statius' father, teaching or studying such authors-especially those closely associated with southern Italy such as Lycophron and the poets who wrote in Doric dialects - may have allowed him to feel connected to his past. ${ }^{135}$ The elder Statius was forging a connection with the Greek world by teaching a variety of great poets, some of whom had a special connection with southern Italy. Following Simon Swain's suggestion about Greeks in the Roman world who were studying their past, this kind of activity may have allowed "local Greek élites to secure their power by allowing them to claim a connection with the recognized leaders of the great days of their countries." 136

Yet it was not just western Greeks who studied these poets. After all, the same Greek poets taught by the elder Statius were taught in Rome throughout the early empire. Even though Rome was a cosmopolitan city full of Greeks, it is hard to imagine that grammatikoi who taught these poets in Rome did not encounter some Roman students. What motivated youths in the capital city to study a wide range of Greek poetry? While poetic aspirations may certainly have motivated some, ${ }^{137}$ a more encompassing explanation is that a knowledge of Greek provided access to sophisticated discourse and a higher degree of "cultural capital" which would allow élite Romans to distinguish themselves and display their knowledge.

\section{PART VIII: GREEK LITERATURE AND ÉLITE ACTIVITY}

Anecdotes in Aulus Gellius' Noctes Atticae demonstrate that Greek poetry indeed formed an important part of aristocratic discourse. Educated people discussed passages of Vergil's poetry which rendered into Latin the Greek of poets such as Homer, Callimachus, and Hesiod (NA 9.9.3). The same anecdote reveals that it is also important to recognize when Vergil wisely omitted Greek phrases from his Latin poetry. In another passage, Favorinus makes a display of his abilities and knowledge when he compares Vergil's description of the eruption of Mt. Aetna with Pindar's (NA 17.10.8-19). ${ }^{138}$ A third discussion about idle chatter cites a line of Epicharmus' poetry to support the speaker's argument ( $N A$ 1.15.15). These accounts - which involve poets taught by the elder Statius-

135. One may also think of the Doric "renaissance" in Hadrianic Sparta. See Cartledge and Spawforth 208-10.

136. Swain 72 .

137. Fantham 175-76.

138. Holford-Strevens 1988: 89 discusses the passage and some of its problems. 
adopt the pretense of being based upon a knowledge of the poetry in question. In actuality, Gellius himself-and others-who participated in such discourse may not have actually known the poets they cite. ${ }^{139}$ A line or passage borrowed from a Favorinus may lurk behind Gellius' discussion of Greek poetry. But if one considers the anecdotes in the wider context of Roman society, what matters is that the discussions took place and that the Roman intelligentsia were "fascinated by learned questions" which were not confined to schoolrooms or lecture halls. ${ }^{140}$ As the work of Gellius demonstrates, these discussions could cover a range of topics, and knowledge of Greek literature would be helpful in any number of them. Aristocrats - the men who sent their children to Statius' father-would know this lesson well, very likely from first-hand experience. These men would also know that if a child learned poetry, his chance for success in intellectual conversation later in life would increase.

Evidence also suggests that it was useful to have a command of Greek that went beyond particular poets or authors. For instance, Fronto could defend Latin from Favorinus' charge that it is an impoverished language by pointing out the multitude of words available in Latin for the color "red." One of these words is spadix, a word Latin took over from Greek-in particular, as Fronto says, from Doric-which means a branch torn from a palm tree with its red fruit still on it (NA 2.26.10). Fronto's appeal to a Doric word in a moment of intellectual competition is remarkable but not unparalleled. Suetonius reports that a certain Xeno was speaking in the presence of Tiberius in recherché terms (Tiberius 56, exquisitius sermocinantem). The emperor, however, finding Xeno's speech troublesome, stopped the orator and asked him in which dialect he was speaking. Xeno responded that the dialect was Doric. It happened that Doric was the dialect spoken on Rhodes, where Tiberius had spent his exile. Consequently, Tiberius thought he was being mocked and banished Xeno to Cinaira. One wonders whether Tiberius, who was fluent in Greek and had wide-ranging literary tastes which included Euphorion (Tiberius 70), truly did not recognize the dialect or was trying to make a statement about his exile. In any case, Tiberius is not the point so much as Xeno. It mattered when one spoke in front of the emperor. Xeno seems to have been aware of this, for, as Suetonius says, his speech was studied. Also significant is that Xeno spoke in Doric at this important moment, suggesting that the dialect had potential value in élite discourse. Banishment was unlikely to be the usual reward for this kind of speech. ${ }^{141}$ The intellectual posturing of Fronto and Xeno is interesting in light of the elder Statius' teaching. If he taught a

139. Holford-Strevens 1988: 171-77 examines Gellius' knowledge of Greek authors.

140. Wallace-Hadrill 1983: 40.

141. In fact, Favorinus informs us that the Syracusans honored a Lucanian ambassador with a statue and a talent of silver because he displayed complete command of the Doric dialect (Corinthiaca 25). Of course, we do not know when the Syracusans honored the Lucanian; the story, if true, could have happened well before the time we are dealing with in this paper. Nonetheless, the anecdote illustrates the value placed on using Doric in oratory. 
number of authors specifically because they were Doric, evidence suggests that this too was likely geared to-and shaping-élite discourse. ${ }^{142}$

These appeals to Greek as a way to distinguish oneself or to maintain position find an interesting contrast in Roman material culture. Roman homeowners also tried to appeal to Greek literature and culture as a way to present themselves as élite. Paul Zanker has discussed attempts of Roman homeowners at Pompeii to incorporate elements of villa architecture into their homes in order to create the illusion that the house was wealthier than it was. Some of these elements - such as watercourses and friezes containing scenes from Homer-appeal to the Greek world to create the impression of wealth and status. But these homeowners did not own villas, and Zanker is surely right to add that their allusions to Greek culture do not indicate a deep knowledge of it. ${ }^{143}$ In fact, the homeowners appeal to familiar Greek stories such as the labors of Hercules or scenes from the Iliad. ${ }^{144}$ These attempts to use Greek culture form an interesting contrast with the activity of students who went to Statius' father and other grammatikoi. Here we find élite youths (5.3.146, generosaque pubes) who had the resources and time to go beyond the familiar and to develop a more sophisticated knowledge of Greek literature and culture. At a time when more and more people made use of the Iliad or other familiar material in their wall paintings - thereby diluting the power of those texts to convey a sense of sophistication-we may wonder whether the élite turned to less conventional and more difficult poets to maintain their status.

At any rate, in comparison with these homeowners and many others in their society, the students who encountered the Greek poets taught by Statius' father and other grammatikoi could lay claim to a rare command of Greek. After all, the poets they studied were not among the core group studied in antiquity. Command of poets such as Homer was likely expected by the élite, but control of (or perhaps even familiarity with) Lycophron would certainly be rarer and therein more prestigious. So what strikes us moderns as obscure authors or language may have had the effect in antiquity of creating distinctions and separating élite from non-élite. A student who studied under the elder Statius and learned the poets he taught would have an impressive ability to engage in sophisticated discourse, to display a paideia advertising his social status and learning. In short, these students had a knowledge which was the "mark of the proper gentleman and constituted per se a claim for public respect and the conferment of positions of honor." 145

Statius informs us that his father's students did in fact go on to positions of honor. When Statius writes of the now grown students of his father, we see that

142. Atherton 224 comments that "If being 'one of us' requires familiarity with the standard dialects of Greek and Latin, and with poetry composed in extinct or literary dialects ... then grammarians must be seen as contributing to the perpetuation of social divisions."

143. Zanker 200.

144. Zanker 148 discusses the themes of the friezes.

145. Wallace-Hadrill 1983: 29. See 26-29 for a discussion of the importance of studia in the early empire. 
they have gained positions in the government and military (5.3.185-90). ${ }^{146}$ My claim is not that learning Corinna's poetry led directly to a government job. The point is rather that looking "Greek is simply part of the Roman uniform." ${ }^{147}$ The elder Statius helped his students put on their uniform, specifically through teaching them Greek poetry. Code-switching has values, and some of these "are related in more indirect ways to the methods people have of calculating honour, or status or prestige." ${ }^{148}$ Simply put, language practices may enhance one's access to power. ${ }^{149}$ It is thus notable that the language which Statius uses to describe the activity of his father's students when they go out into the world is redolent of power. One is a magistrate (5.3.186, alter / iura dat), another restrains Iberians (5.3.186, alter compescit Hiberas), a third guards borders (5.3.187, alter Achaemenium secludit Zeu $<$ g>mate Persen), others are judges or legislators (5.3.188-90, hi dites Asiae populos, hi Pontica frenant, / hi fora pacificis emendant fascibus, illi / castra pia statione tenent). We need not think that Statius had specific students in mind when he wrote these verses. The students who have acquired these positions are a type-the kind of student produced by a good grammarian. What is intriguing is that the way in which Statius imagines them performing after they have been taught by his father could have been predicted from other sources of education in the early Roman empire. ${ }^{150}$

\section{PART IX: DO AS I SAY (AND DO)}

Greek intellectuals were prized at Rome and the imperial courts were full of them. ${ }^{151}$ The elder Statius himself may even provide an example of someone whose knowledge and command of Greek literature garnered attention in Roman society. In sharp contrast with most grammarians, who did not have a prominent

146. Vollmer 541 takes the phrase ex illo grege (5.3.185) to refer specifically to the students of Roman religion. It seems to me that Vollmer creates a distinction which is not so strong in the Latin and that it is just as possible that ex illo grege refers to all the students. Statius segues immediately from the father's students on the Bay of Naples to the religion students, and concludes his discussion by referring to all of his father's students.

147. Wallace-Hadrill 1998b: 88.

148. Heller 160.

149. Heller 161 writes, "Language practices ... are ... among the ways individuals have at their disposal of gaining access to the production, distribution and consumption of symbolic and material resources." See also Wallace-Hadrill 1988: 225: "Classicists . . have long tried to persuade themselves that knowledge and power are separate and separable worlds; that the study of history is distinct from the study of culture; that the intellectual world is tangential to the world of war and politics. The Romans were not so naïve."

150. It should also be noted that ethics were a key point in ancient education (see Atherton 229-34). By learning rules of grammar, students also learned to understand rules in determining what was and what was not correct in their life (Atherton 242). Statius certainly connects a moral component with the study of the Greek poets taught by his father (5.3.146ff., hinc tibi vota patrum credi generosaque pubes / te monitore regi, mores et facta priorum / discere, quis casus Troiae, quam tardus Ulixes, / quantus equum pugnasque virum decurrere versu/Maeonides ...).

151. See Syme 1-20; Wallace-Hadrill 1983: 78-86. 
status in Rome and Roman society, Statius' father achieved some importance. ${ }^{152}$ Alex Hardie suggests, for example, that Nero may have offered the elder Statius patronage and brought him to Rome. ${ }^{153}$ Moreover, it has been argued that when he came to Rome, Statius' father taught the young Domitian (5.3.178). ${ }^{154}$ The inscription in Athens may in fact honor the father's extraordinary accomplishments. The factual basis of these three points remains uncertain. If any one were true, it would attest to his significant status. ${ }^{155}$ It is clear, however, that the father eventually drew the attention of the Caesars by writing a poem on the civil wars of 68-69 (5.3.203-204). With this, he certainly moves beyond the typical grammarian. Statius does not say in which language the poem was written, so there is no reason to assume that the poem was written in Greek. Yet, given the Roman interest in Greek intellectuals, it would seem rash to suggest that the elder Statius' ability to move between Greek and Latin - to code-switch-was not attractive at Rome. What mattered was that he was socially eminent in Naples and had a prominence in literature and rhetoric. These two factors suggest that Statius' father fits very nicely into the pattern of outsiders who gain the attention of the emperor. ${ }^{156}$ Statius' father gained access to élite circles and eventually to the Roman imperial court through outstanding achievements in Greek, and thereby provided a powerful example to his students.

Smith College

cmcnelis@smith.edu

\section{BIBLIOGRAPHY}

Aricò, G. 1981. "La scuola di Papino." Atti del Congresso Internazionale di Studi Vespasianei II, 315-23. Rieti.

Atherton, C. 1998. "Children, animals, slaves and grammar." In Y.L. Too and N.

Livingstone, eds., Pedagogy and Power, 214-44. Cambridge.

Bloomer, W. M. 1997. Latinity and Literary Society at Rome. Philadelphia.

Bonner, S. F. 1977. Education in Ancient Rome. Berkeley.

Bourdieu, P. 1977. Outline of a theory of practice. Trans. R. Nice. Cambridge.

Bubeník, V. 1989. Hellenistic and Roman Greece as a Sociolinguistic Area. Amsterdam. Burzacchini, G. 1992. "Corinna in Roma." Eikasmos 3: 47-65.

152. See Atherton $220-22,228$ for the relatively low status of grammarians. I am making no suggestions about Statius' social rank.

153. Hardie 15.

154. Hardie 10-11 is a recent discussion of the implications of Statius' reference to the Pontifex Maximus and its relationship to Domitian. H. J. van Dam 2736 and others have questioned the claim.

155. See also the discussion of Aricò 321.

156. Millar 60 writes: "But in historical importance the influence of the freedmen is far outweighed by that of men who came into the emperor's service from outside. It is crucial to the whole nature of the imperial function, and by implication also to the values of the societies from which it grew, that the qualifications of these men were, typically, first a social eminence in their native cities, and second a prominence in literature and rhetoric." 
Cairns, F. 1999. "Epaphroditus, ФAINIANOKOPIOI $\Sigma$ and 'Modestus' (Suda $\varepsilon 2004) . "$ ZPE 124: 218-22.

Cameron, A. 1995. Callimachus and his Critics. Princeton.

Cartledge, P., and A. Spawforth. 1989. Hellenistic and Roman Sparta. London.

Christes, J. 1979. Sklaven und Freigelassene als Grammatiker und Philologen im antiken Rom. Wiesbaden.

Clinton, K. 1972. "Publius Papinius St[-] at Eleusis." TAPA 103: 79-82.

Connolly, J. 1998. "Mastering Corruption: Constructions of Identity in Roman Oratory." In S. Joshel and S. Murnaghan, eds., Women and Slaves in Greco-Roman Culture, 131-50. London.

Cribiore, R. 1996. Writing, Teachers and Students in Greco-Roman Egypt. Atlanta.

Cronert, W. 1912. "Die Sprüche des Epicharm." Hermes 47: 402-13.

Daniel, R. W. 1996. "Epicharmus in Trier: A Note on the Monnus-Mosaic." ZPE 114: 30-36.

Debrunner, A. 1954. Geschichte der griechischen Sprache II: Grundfragen und Grundzïge des nachklassischen Griechisch. Berlin.

Dewar, M. J. 1991. Statius: Thebaid IX. Oxford.

Dionisotti, A. C. 1982. "From Ausonius' Schooldays? A Schoolbook and its Relatives." JRS 72: 83-125.

Dubois, L. 1989. Inscriptions grecques dialectales de Sicilie. Rome.

Fantham, E. 1996. Roman Literary Culture. Baltimore.

Feeney, D. 1998. Literature and Religion at Rome. Cambridge.

Fehrle, R. 1986. Das Bibliothekwesen im alten Rom. Wiesbaden.

Fraser, P. M. 1972. Ptolemaic Alexandria. Oxford.

Gleason, M. W. 1995. Making Men. Princeton.

Gossage, A. J. 1965. "Papinius, The Father of Statius." Romanitas 7: 171-79.

Gow, A. S. F. 1950. Theocritus. Cambridge.

Guarducci, M. 1969. Epigrafia Greca II. Rome.

Hardie, A. 1983. Statius and the Silvae. Liverpool.

Heller, M. 1995. "Code-switching and the politics of language." In L. Milroy and P. Muysken, eds., One speaker, two languages. Cross-disciplinary approaches on code-switching, 158-74. Cambridge.

Hillscher, A. 1892. "Hominum litteratorum Graecorum ante Tiberii mortem in urbe Roma commoratorum historia critica." Jahrbücher für classische Philologie Sup. Band XVIII: 354-444.

Holford-Strevens, L. 1988. Aulus Gellius. London.

- 1993. "Bilingualism in the Roman Empire." In H. Jocelyn, ed., Tria Lustra: Essays and notes presented to John Pinsent, 203-13. Liverpool.

- 1997. "Aulus Gellius: The Non-Visual Portraitist." In M. J. Edwards and S. Swain, eds., Portraits: Biographical Representation in the Greek and Latin Literature of the Roman Empire, 93-116. Oxford.

- forthcoming. "In search of Poplios Papinios Statios." Hermathena.

Jones, C. P. 1971. Plutarch and Rome. Oxford.

Kaibel, G. 1899. Comicorum Graecorum Fragmenta. Berlin.

Kaimio, J. 1979. The Romans and the Greek Language. Helsinki.

Kaster, R. 1988. Guardians of Language. Berkeley.

. 1995. C. Suetonius Tranquillus: De Grammaticis et Rhetoribus. Oxford. 
LaPenna, A. 1979. Fra teatro, poesia e politica romana: Politica e cultura in Roma antica e nella tradizione classica moderna. Turin.

Lardi, A. 1971. "I dialetti dorici in Sicilia." RAAN 46: 3-42.

Laurence, R. 1994. Roman Pompeii. London.

Legras, L. 1905. Étude sur la Thébaïde de Stace. Paris.

Lehnus, L. 1994. "Epafrodito F 27 L, Erodoro e Callimaco." Sileno 20: 369-73.

Leiwo, M. 1994. Neapolitana: A Study of Population and Language in Greco-Roman Naples. Helsinki.

Lobel, E. 1956. The Oxyrhynchus Papyri XXIII. London.

- 1957. The Oxyrhynchus Papyri XXIV. London.

. 1967. The Oxyrhynchus Papyri XXXII. London.

Lobel, E., and D. Page. 1955. Poetarum Lesbiorum Fragmenta. Oxford.

Lomas, K. 1993. Rome and the Western Greeks 350 BC-200 AD. London.

Luenzner, E. 1866. Epaphroditi grammatici quae supersunt. Bonn.

Mazzarino, A. 1955. Grammaticae Romanae Fragmenta Aetatis Caesareae. Turin.

Millar, F. 1977. The Emperor in the Roman World. Ithaca.

Milroy, L., and P. Muysken. 1995. One speaker, two languages. Cross-disciplinary approaches on code-switching. Cambridge.

Miranda, E. 1990. Iscrizioni greche d'Italia: Napoli I. Rome. . 1995. Iscrizioni greche d'Italia: Napoli II. Rome.

Mommsen, T. 1883. Corpus Inscriptionum Latinarum: Voluminis Decem Pars Prior. Berlin.

Morgan, T. 1998. Literate Education in the Hellenistic and Roman Worlds. Cambridge.

Ogilvie, R. M. 1978. The Library of Lactantius. Oxford.

Önnerfors, A. 1974. Vaterporträts in der römischen Poesie unter besonderer Berücksichtigung von Horaz, Statius und Ausonius. Stockholm.

Paci, G. 1991. "Tito a Salerno." In Epigrafia. Actes du colloque en mémoire de Attilio Degrassi, 692-704. Rome.

Page, D. L. 1951. Alcman: The Partheneion. Oxford.

- 1963a. Corinna. London.

1963b. The Oxyrhynchus Papyri XXIX. London.

Parsons, P. J. 1977. "Callimachus: Victoria Berenices." ZPE 25: 1-50.

Peek, W. 1955. Griechische Vers-Inschriften. Berlin.

Pfeiffer, R. 1953. Callimachus II. Oxford.

- 1968. History of Classical Scholarship. Oxford.

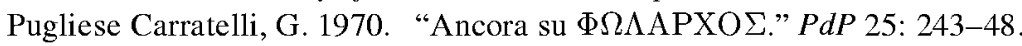

Rawson, E. 1985. Intellectual Life in the Late Roman Republic. London.

Romeo, C. 1988. Demetrio Lacone: La Poesia (P.Herc. 188 e 1014). Naples.

Schmid, W., and O. Stählin. 1929. Geschichte der Griechischen Literatur. Munich.

Swain, S. 1996. Hellenism and Empire. Oxford.

Syme, R. 1988. Roman Papers IV. A. Birley, ed. Oxford.

Traglia, A. 1965. "Il Maestro di Stazio." RCCM 7: 1128-34.

Turner, E. G. 1975. “Oxyrhynchus and Rome." HSCP 79: 1-24.

Van Dam, H. J. 1986. "Statius 'Silvae': Forschungsbericht 1974-84." ANRW 2.32.5: 2727-53.

Van Rossum-Steenbeek, M. 1988. Greek Readers' Digests? Studies on a Selection of Subliterary Papyri. Leiden.

Vollmer, F. 1898. P. Papinii Statii Silvarum Libri. Leipzig. 
Wallace-Hadrill, A. 1983. Suetonius. London.

. 1988. "Greek Knowledge, Roman Power." CP 83: 224-33.

. 1998a. "Vivere alla greca per essere Romani." In S. Settis, ed., I Greci. Storia

Cultura Arte Società 2. Una storia greca. III Trasformazioni, 939-63. Turin.

- 1998b. "To Be Roman, Go Greek. Thoughts on Hellenization at Rome." In

M. Austin, J. Harries, and C. Smith, eds., Modus Operandi: Essays in Honour of Geoffrey Rickman, 79-91. London.

West, M. L. 1978. Hesiod: Works and Days. Oxford.

. 1982. Greek Metre, Oxford.

West, S. 1983. "Notes on the Text of Lycophron." CQ 33: 114-35.

Wilamowitz-Moellendorff, U. von. 1924. Hellenistische Dichtung II. Berlin.

Wilkins, E. 1914. Roman Education. Cambridge.

Wilson, R. J. A. 1990. Sicily under the Roman Empire. Warminster.

Woolf, G. 1994. "Becoming Roman, Staying Greek: Culture, Identity and the Civilizing Process in the Roman East." PCPS 40: 116-43.

- 1998. Becoming Roman. Cambridge.

Wouters, A. 1979. The Grammatical Papyri from Greco-Roman Egypt: Contributions to the Study of the "Ars Grammatica" in Antiquity. Brussels.

Zanker, P. 1998. Pompeii. Cambridge.

Zgusta, L. 1980. “Die Rolle des Griechischen im römischen Kaiserreich.” In G. Neumann and J. Untermann, eds., Die Sprachen im römischen Reich der Kaiserzeit, 121-45. Cologne. 